\title{
The Nasotemporal Division of Retinal Ganglion Cells with Crossed and Uncrossed Projections in the Fetal Rhesus Monkey
}

\author{
Leo M. Chalupa and Barry Lia \\ Department of Psychology, the Center for Neurobiology, and the California Primate Research Center, University of \\ California, Davis, California 95616
}

The development of the partial decussation pattern in the primate retina was studied in fetal rhesus monkeys of known gestational ages. Retinal ganglion cells with either crossed or uncrossed projections were identified by labeling with HRP following unilateral injections of this tracer into the optic tract. At all fetal ages, very few cells (less than $0.5 \%$ of the total ganglion cell population) were found to project to the inappropriate hemisphere. The nasotemporal overlap zone, defined as the retinal region along the vertical meridian containing cells with either crossed or uncrossed projections, also appeared equivalent to that described for the adult animal. A temporal offset in the decussation pattern of large ganglion cells, similar to that of the mature retina, could be recognized as early as $50 \mathrm{~d}$ before birth. These results indicate that an adultlike retinal decussation pattern is evident in the fetal primate at a stage when projections from the 2 eyes are completely intermingled within retinorecipient nuclei, and prior to the onset of retinal ganglion cell loss. Moreover, the primate visual system exhibits a degree of precision in the specification of the nasotemporal division unrivaled among the mammalian species studied to date. The developmental specificity evident in the decussation pattern of the fetal rhesus monkey appears to reflect the specialized organization of this primate's retina for binocular focal vision.

Retinal decussation patterns form a key component of the neural mechanisms underlying binocular depth perception. A hallmark of the primate visual system is a strict nasotemporal division of retinal ganglion cells with crossed and uncrossed projections. All ganglion cells in the temporal hemiretina project to the ipsilateral hemisphere, whereas those in the nasal hemiretina project contralaterally. Along the vertical meridian, there is a limited overlap zone where cells with either crossed or uncrossed projections are intermixed (Stone et al., 1973; Bunt et al., 1977; Leventhal et al., 1988a; Fukuda et al., 1989). In nonprimate mammals, on the other hand, crossed projections arise from the

\footnotetext{
Received May 4, 1990; revised Aug. 30, 1990; accepted Sept. 5, 1990.

This work was supported by NIH Grants RR-00169 and EY-03991. We thank Dr. John Anderson of the California Primate Research Center (CPRC) for performing the fetal surgeries, Dr. Alice Tarantal for ultrasonography, and Ms. C. J. Snider for her valuable contributions to all the technical phases of this project. We are also indebted to Dr. Andrew G. Hendrickx, director of the CPRC, for his support of this research program.

Correspondence should be addressed to Leo M. Chalupa, Psychology Department, University of California, Davis, CA 95616.

Copyright (C) 1991 Society for Neuroscience $0270-6474 / 91 / 010191-12 \$ 03.00 / 0$
}

entire contralateral retina, so that ganglion cells (of certain classes) with either crossed or uncrossed projections are intermingled throughout the temporal hemiretina (Stone, 1966; Cooper and Pettigrew, 1979; Dräger and Olson, 1980; Wässle and Illing, 1980; Provis and Watson, 1981; Pettigrew et al., 1984; Vitek et al., 1985; Wakakuwa et al., 1985; Reese and Cowey, 1987).

How the partial decussation patterns of mammalian retinal ganglion cell projections are established is as yet poorly understood. Studies on rodents (Jeffery and Perry, 1982; Bunt et al., 1983; Martin et al., 1983; Insausti et al., 1984; Jeffery, 1984; Godement et al., 1987; Collelo and Guillery, 1990) and carnivores (Jacobs et al., 1984; Morgan and Thompson, 1985; Lia et al., 1987a; Leventhal et al., 1988b) have demonstrated that, while an overall retinal decussation pattern can be recognized early in development, a substantial number of ganglion cells are located in the inappropriate hemiretinas. For instance, in the fetal rat, more than $40 \%$ of the ipsilaterally projecting retinal ganglion cells are distributed outside the temporal crescent, the region of the retina to which the uncrossed projection is confined at maturity (Jeffery, 1984). In the developing cat (Lia et al., 1987a) and ferret (Morgan and Thompson, 1985), approximately $12 \%$ of ganglion cells with uncrossed projections are located outside the temporal hemiretina. As development proceeds, these ectopic cells are normally eliminated by a wave of selective ganglion cell death (Fawcett et al., 1984; Insausti et al., 1984).

In the present study, we examined the prenatal decussation pattern of retinal ganglion cell projections in the rhesus monkey (Macaca mulatta). We were especially interested in determining whether the nasotemporal division of the primate retina is sculpted by selective ganglion cell death from a decussation pattern characteristic of nonprimate mammals or whether this unique feature of the primate visual system is inherent to the developing retina. If the former were the case, this would suggest that central mechanisms (e.g., axon-target interactions) play a key role in establishing the primate nasotemporal division. On the other hand, the latter outcome would indicate that the primate pattern is "imposed" by the retina upon the developing visual system.

Our findings unequivocally support the second alternative. Very few retinal ganglion cells were found to project to the inappropriate hemisphere at all gestational ages studied. A remarkably adultlike nasotemporal division of the retina is present in this primate even prior to the onset of the period of ganglion cell death.

Some of these results were reported previously in abstract form (Lia et al., 1988) 

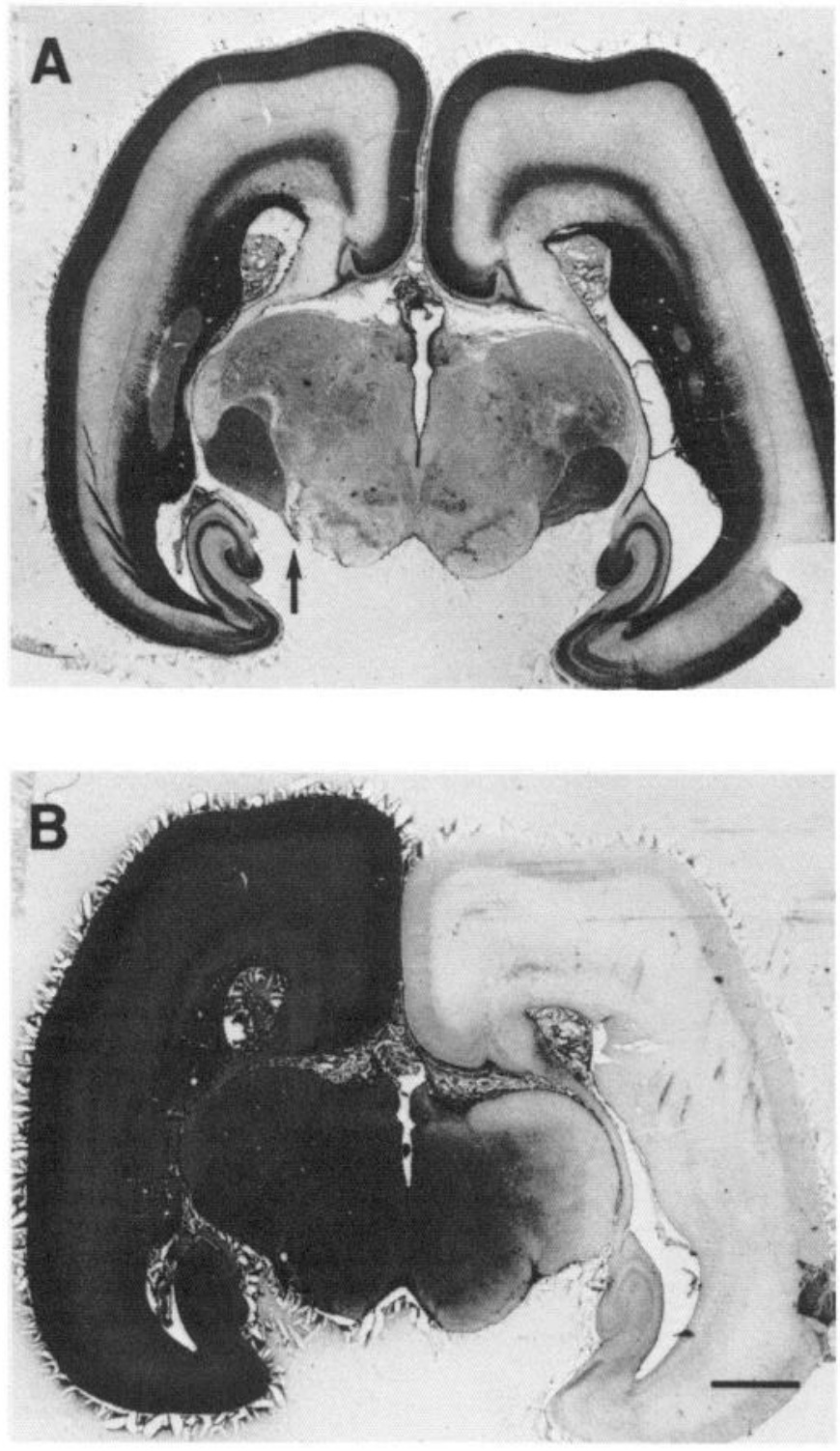

Figure 1. Frontal sections at level of LGN from fetus at E85. A, The geniculate nuclei are darkly stained for Nissl substance. One of the multiple needle tracks made during injection can be seen just medial to the left LGN at the base of the thalamus (arrow), interrupting the course of the optic tract. $B$, Adjacent section reacted for peroxidase activity. Although reaction product is evident across the midline, the effective uptake zone did not involve retinorecipient nuclei of the contralateral hemisphere (see text). Scale bar, $2.5 \mathrm{~mm}$.

\section{Materials and Methods}

Four fetal rhesus monkeys (Macaca mulatta) were studied at embryonic (E) days E69, E85, E115, and E129 $( \pm 2)$. Full gestation in the rhesus macaque lasts about $165 \mathrm{~d}$. Description of the breeding protocol and the estimation of gestational age have been provided in a previous publication (Killackey and Chalupa, 1986).

Ultrasonography. To facilitate the accurate placement of fetal injections, ultrasonography was employed prior to in utero surgery. The pregnant animal was anesthetized with ketamine, and ultrasonographic measurements of the fetal brain were taken in the frontal, transverse, and sagittal planes to determine the position of the optic chiasm and the ventrolateral margins of the thalamus. Measurements were recorded on ultrasonographic images using a real-time mechanical sector-scanning device equipped with internal electronic calipers (Advanced Technologies Laboratories, Inc., MK600).
Injections. All surgical procedures were carried out in accordance with $\mathrm{NIH}$ guidelines. After anesthetic induction with ketamine $(10 \mathrm{mg} / \mathrm{kg})$, the pregnant animal was intubated and maintained at a surgical plane of anesthesia with halothane (1-2\%) in a $30 \%$ oxygen, $70 \%$ nitrous oxide mixture. This anesthetic readily passes from the placenta to the fetus. Following uterotomy, the fetal head was exteriorized and kept moist with warm saline. In the youngest fetuses (E69 and E85), injections were made through the developing cranial bone with a sharp 22-gauge needle attached to a Hamilton microsyringe. In older fetuses, a partial craniotomy was required. The needle was marked for depth of penetration, and placement was guided by the ultrasonographic measurements. A total of 3-12 $\mu \mathrm{l}$ (depending on the age of the fetus) of 50\% horseradish peroxidase in $2 \%$ dimethylsulfoxide was delivered in multiple small amounts at several depths, and at different anteroposterior levels, to ensure the involvement of the entire optic tract of one hemisphere. The head was then sutured and returned to the uterus, and all incisions were closed. Fetal viability was monitored by ultrasonography, and a postoperative analgesic, oxym orphone $(0.15 \mathrm{mg} / \mathrm{kg} 3$ times daily), was routinely administered.

Histology. Following a 24-hr period of retrograde transport of the tracer, the pregnant animal was reanesthetized as described above. The fetus was delivered by cesarean section, killed with barbiturate, and transcardially perfused with heparinized, buffered saline followed by fixative ( $1 \%$ paraformaldehyde, $3 \%$ glutaraldehyde). The eyes were removed immediately and immersed in buffered saline. Perfusion was then continued with $10 \%$ sucrose buffer. All solutions were adjusted to pH 7.4 with $0.1 \mathrm{~m}$ phosphate buffer. The brain was later removed, immersed overnight in $20 \%$ sucrose-buffer solution for cryoprotection, and subsequently sectioned frozen at $50 \mu \mathrm{m}$. Alternate sections were either stained with thionin for Nissl substance or reacted for peroxidase activity using diaminobenzidine as the chromogen (Adams, 1981).

The anterior chamber of each eye was opened to remove the lens and vitreous body. Short orienting cuts were made in the retinal periphery along the nasal and temporal long posterior ciliary arteries. The retinas were then dissected free and reacted for peroxidase activity employing a metal-intensified pyrocatechol-phenylenediamine protocol (Hanker et al., 1977; Perry and Linden, 1982) modified to use $0.1 \mathrm{~m}$ cacodylate buffer $(\mathrm{pH}, 5.1)$ throughout. In order to flat-mount the retinas, further cuts were made directed towards the "posterior temporal bulge" (Streeten, 1969), the site of the future fovea centralis. The retinas were then flattened onto a gelatinized slide under a polycarbonate membrane, filter paper, and weighted coverglass and fixed overnight with $2 \%$ glutaraldehyde in cacodylate buffer. The retinas were dehydrated in dimethylsulfoxide, cleared in glycerol, and coverslipped. Such processing causes minimal shrinkage of whole-mount tissue (Curcio et al., 1987; Packer et al., 1989).

Data analysis. Both labeled and unlabeled cell profiles could be distinguished using differential interference contrast (DIC) microscopy. The sharp depth of field of DIC microscopy affords an optical section of tissue that is invaluable for counting in the presumptive fovea centralis region and in the developing foveal slope where cells are densely packed. Cells were considered labeled only if grains of reaction product were visible within the cell profile in one sharp plane of focus.

The distribution of labeled cells in each retina was assessed by counting cells within an ocular reticle (either $45 \mu \mathrm{m}^{2}$ or $174 \mu \mathrm{m}^{2}$ ) at sampling sites distributed at least every $0.5 \mathrm{~mm}$ in a square grid array across the entire retinal surface. All counting was done according to Gundersen's rule (1977). This corrects for the "edge effect" by treating 2 adjacent sides of the reticle as exclusion borders in a tessellated array of reticle spaces. Cell densities (cells $/ \mathrm{mm}^{2}$ ) were calculated by proportionality [(counts/reticle area) $\times\left(\right.$ number of reticle areas $\left.\left./ \mathrm{mm}^{2}\right)\right]$ and plotted on a projection drawing of the whole-mount.

The hemiretinal median edge is defined as the nasotemporal border beyond which only scattered labeled cells are found (Stone, 1966; Stone et al., 1973). This border was determined by inspection under low power and plotted upon the projection drawing of the whole-mount. Population estimates were then calculated from the labeled cell density distribution relative to the median edge in order to obtain both the orthotopic and ectopic cell populations.

To assess the sharpness of the nasotemporal border, sampling transects of both labeled and unlabeled cell density were taken at several eccentricities along the vertical meridian. Across a given transect, cell profiles were counted within adjacent ocular reticles (either $45 \mu \mathrm{m}^{2}$ or $174 \mu \mathrm{m}^{2}$ ) moving perpendicular to the nasotemporal division. In peripheral retina, an averaging function was applied across 5 adjacent counts to smooth the raw values in each transect. 

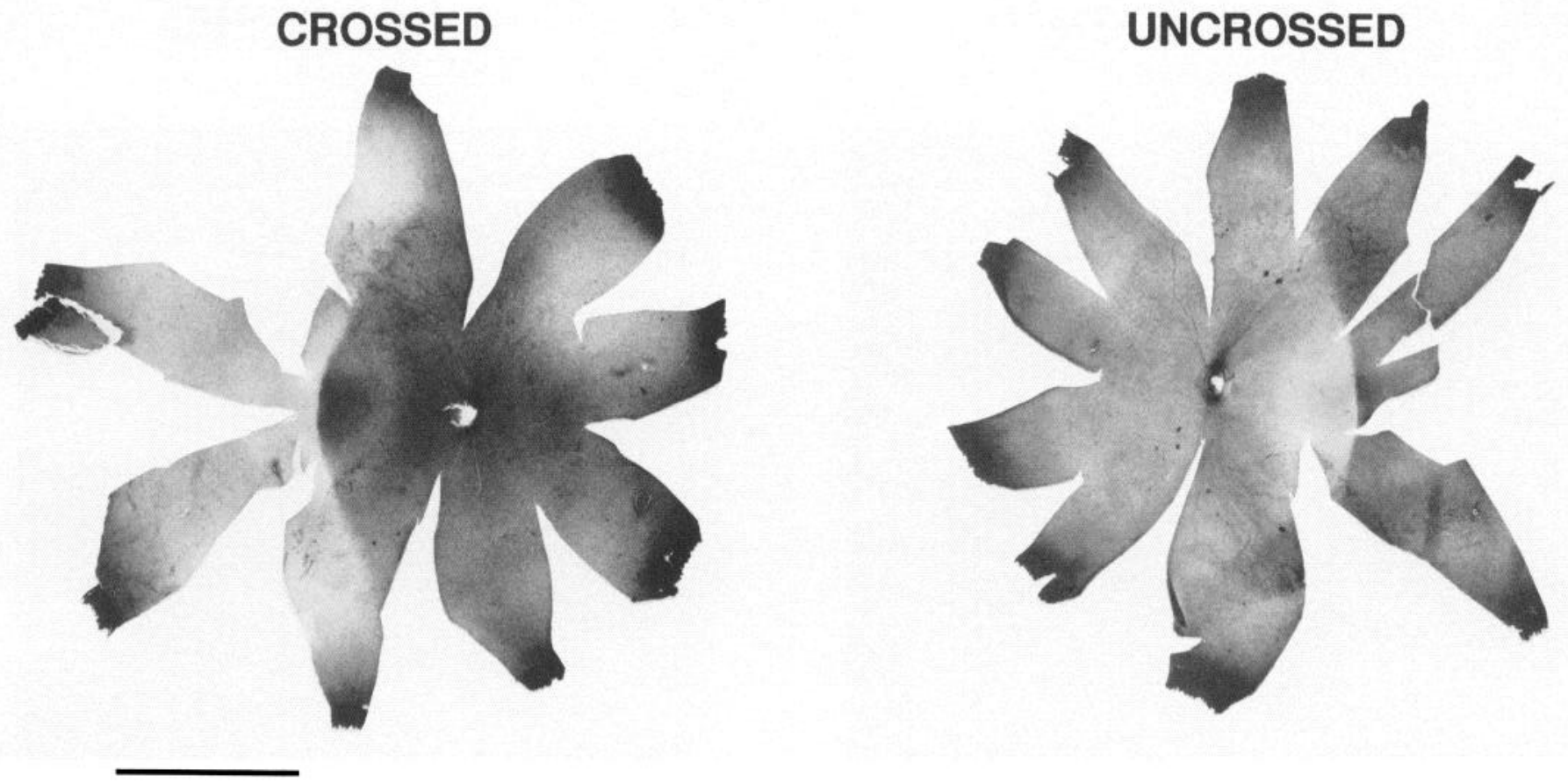

Figure 2. Photographs of retinal whole-mounts at E85 reacted for peroxidase activity following injection shown in Figure 1. Left, Retinal ganglion cell labeling contralateral to the injected optic tract, demonstrating the restricted nasal hemiretinal distribution of the crossed population. Right, Labeling ipsilateral to the injection, showing the temporal hemiretinal distribution of the uncrossed population. Scale bar, 5 mm.

For soma size analyses, cell profiles were drawn at the widest soma diameter using DIC optics with a camera lucida $(2200 \times)$ and subsequently traced on a digitizing tablet for measurement of soma area $\left(\mu \mathrm{m}^{2}\right)$. To analyze the distribution of soma sizes within the nasotemporal overlap zone, labeled cells were drawn within a corridor $2 \mathrm{~mm}$ across and $275 \mu \mathrm{m}$ wide centered on a nascent fovea $( \pm 7.5 \mu \mathrm{m})$. All labeled profiles were drawn within the contralateral temporal and ipsilateral nasal sectors, while systematic sampling was used for the high-density ipsilateral temporal and contralateral nasal sectors. These sampled profiles were drawn at all depths of the ganglion cell layer in order to avoid bias due to the stratification of different retinal ganglion cell classes within central retina (Perry and Silveira, 1988). To compare the soma sizes of ectopic ganglion cells with those projecting to the appropriate hemisphere, labeled cell profiles were drawn within a sector of temporal retina beyond $5 \mathrm{~mm}$ eccentricity. Contralateral to the injected optic tract, all ectopic cells within this sector were drawn, whereas a systematic sample of labeled profiles was drawn within an equivalent sector of the ipsilateral temporal hemiretina.

\section{Results}

The results are based on 4 fetal animals in which injections of HRP were placed successfully in the optic tract of one hemisphere, and in which there was no spread of tracer to the optic pathway of the contralateral hemisphere, as illustrated in Figure 1. In this E85 fetus, as in all the others, the dorsal lateral geniculate nuclei could be readily discerned in Nissl-stained sections (Fig. 1A). The tracer was delivered into the optic tract along the ventrolateral thalamus. In alternate sections, not counterstained, reaction product was evident throughout the injected hemisphere, as well as in the medial thalamus of the contralateral hemisphere (Fig. $1 B$ ). However, in all of the cases reported here, there was no uptake of tracer by ganglion cells projecting to the contralateral hemisphere. This was confirmed by the absence of retrogradely labeled neurons within the infragranular layers of the contralateral striate cortex, which also project to the lateral geniculate and superior colliculus on the same side.

Such injections resulted in robust labeling of ganglion cells in the entire contralateral nasal hemiretina and in the entire ipsilateral temporal hemiretina. This was clearly evident in wholemounted retinas even without magnification (Fig. 2). In all cases, the boundary between the 2 hemiretinas was very sharp, as illustrated in the photomicrographs of Figure 3. Quantitative analysis of labeled cell density confirmed this impression. As may be seen in Figure 4, which depicts the distributions of labeled cell densities in the E85 retinas, very few cells were labeled in the inappropriate hemiretinas of the ipsilateral and the contralateral eyes. In all retinas, a clear central-to-peripheral gradient in ganglion cell density was evident (Lia and Chalupa, 1988), so that even in the youngest retina (E69), the area centralis (future site of the fovea) could be recognized by its high density of labeled cells. The fovea centralis was discernable at E85 by a thinning of the ganglion cell layer; however, the foveal slope was still relatively shallow even in the E129 retina.

\section{Decussation errors}

To quantify the number of ectopic cells, we estimated the population of labeled neurons beyond the median edge of the appropriate hemiretinas (i.e., cells in the nasal hemiretina ipsilateral to the injection and cells in the contralateral temporal hemiretina). At every fetal age, the number of such cells in both retinas was miniscule relative to the total number of labeled cells. At E69, there were only 2600 such ectopic cells out of a labeled cell population of $841,000(0.31 \%)$. At about midgestation (E85), these values were 6100 out of $1,578,000(0.39 \%)$. The ectopic cell ratio was $4100: 1,731,000(0.24 \%)$ at E1 15 and $2300: 1,171,000(0.20 \%)$ at E129. Thus, throughout the period of fetal development we have studied, no more than $0.5 \%$ of the ganglion cell population projects to the inappropriate hemisphere. Ganglion cells that project to the "wrong" hemisphere have even been noted in the adult macaque retina, but their 


\section{CROSSED}



UNCROSSED



Figure 3. Photomicrographs of area centralis regions of 2 E85 whole-mounts shown in Figure 2, presented in same orientation (nasal, medial; temporal, to the outside). Note the sharp demarcation of both the crossed and the uncrossed projections. Scale bar, $250 \mu \mathrm{m}$.

number remains to be quantified (Perry and Cowey, 1984; Y. Fukuda and M. Watanabe, personal communication).

As shown in Table 1, the incidence of ectopic cells is not significantly greater in the contralateral temporal retina than in the ipsilateral nasal retina. These data indicate that the specialized primate retinal decussation pattern does not arise from a pattern resembling that of nonprimate mammals.

\section{Nasotemporal overlap of crossed and uncrossed projections}

In the adult macaque retina, there is a "median strip of overlap" running along the vertical meridian in which ganglion cells projecting to either hemisphere are intermingled (Stone et al., 1973; Fukuda et al., 1989). At maturity, this nasotemporal overlap zone is narrowest in the central retina, progressively increasing in width towards the lower and upper parts of the retina. This feature of the retinal decussation pattern can be delineated by assessing changes in labeled cell densities perpendicular to the vertical meridian at different eccentricities (cf. Illing and Wässle, 1981). As illustrated in the photomicrographs of Figure 5, along the vertical meridian, there is a zone of transition across which labeled cell density declines from a maximum to a minimum.

The width of this transition zone was determined by plotting cell densities in adjacent reticules across sampling transects that were oriented perpendicular to the median edge. Each transect generated a sigmoid curve of labeled cell density as depicted in Figure 6 . The left arrowhead corresponds to the median edge of the labeled uncrossed projection. It is important to point out that the total cell density (labeled and unlabeled profiles) is relatively uniform across each transect, as shown in Figure 6. Because a countervailing population of crossed cells must be present in order to maintain uniform total cell density, the right arrowhead represents the median edge of the crossed projection. Identical measures of the transition zone were obtained for the crossed projection. Thus, this zone of transition in labeled cell density along the vertical meridian represents the nasotemporal overlap zone.

Figure 7 illustrates the widths of the overlap zone at 3 different eccentricities in the E1 15 fetus. The slopes of the curves indicate that the overlap zone is narrower closer to the developing fovea centralis, widening at greater eccentricities. From a number of such transects (11-16 per retina), we determined the extent of the nasotemporal overlap zone and plotted this on projection drawings of the retinal whole-mounts. As shown in Figure 8, the shape of the overlap zone is remarkably similar at E69 and E115. At both ages, it is hourglass shaped, with the narrowest portion centered on the presumptive fovea centralis. Even a relatively subtle feature of the mature overlap zone, its greater width in the superior than inferior retina (Fukuda et al., 1989), is already evident at E69. At these 2 fetal ages, the extent of the nasotemporal overlap zone is essentially identical at equivalent eccentricities, despite the substantial growth of the retina. Indeed, the overlap zone of the E69 retina matches precisely the central segment of the E115 zone. This indicates minimal expansion of the central retina and differential growth of the retinal 

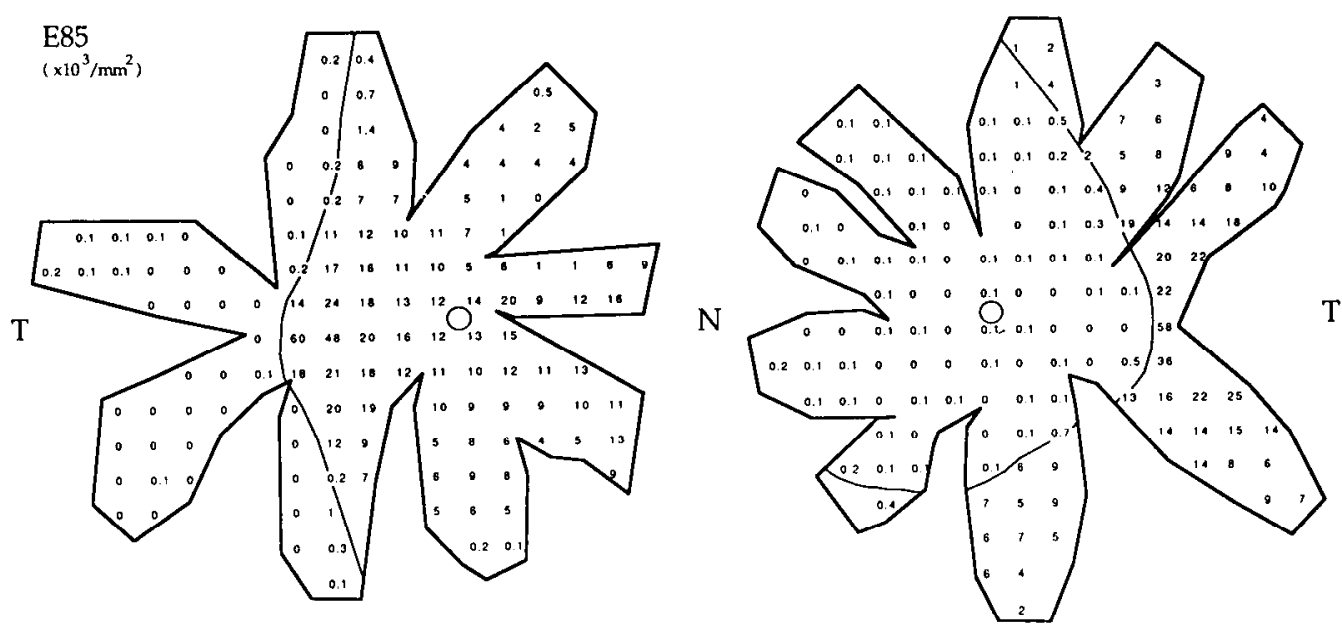

Figure 4. Labeled cell density at sampling points distributed across retinas of E85 fetus. Numbers represent density in labeled cells $\times 10^{3} / \mathrm{mm}^{2}$. For clarity, only every other point sampled is illustrated in this schematic. Lines demarcate the boundary between the labeled and unlabeled hemiretinas. Circles mark the optic disks. $T$, temporal; $N$, nasal.

periphery during fetal development (Lia et al., 1987b; Lia and Chalupa, 1988).

\section{Class-specific decussation pattern: temporal offset of large cells}

In the mature macaque retina, there is evidence, based largely on analysis of soma sizes, that different classes of ganglion cells are characterized by distinct nasotemporal overlap patterns. Large ganglion cells, presumably corresponding to the P $\alpha$ (Perry et al., 1984) or A class (Leventhal et al., 1981), are characterized by a decussation line that is offset temporal to the overall population of ganglion cells (Fukuda et al., 1989). In our material, a distinct large cell population of labeled cells was evident by E115. In particularly well-filled cells, the proximal dendritic morphology of these neurons clearly resembled that of $\mathrm{P} \alpha$ cells (Fig. 9). As in the adult (Fukuda et al., 1989), such cells were more abundant along the temporal median edge of the crossed projection population than along the nasal median edge of the uncrossed population.

Figure $10 \mathrm{~A}$ illustrates tracings of labeled cell profiles across the nasotemporal overlap zone centered on the nascent fovea of the E115 retina. The figure is a composite of cells in the 2 retinas, so that the cells in the temporal sector are contralateral to the injected hemisphere (Fig. 10, CT), whereas those in the nasal sector are ipsilateral (Fig. 10, UN). By this age, the foveal pit is recognizable, providing a landmark for the proper alignment of the 2 retinas. A straight band of overlap about 175 $200 \mu \mathrm{m}$ wide passes through the developing fovea, offset some- what nasal to the nascent foveal center. It may be seen that there is a dispersion of labeled cells in the temporal sector, extending about $400 \mu \mathrm{m}$ from the vertical meridian. Importantly, profiles of these dispersed cells in the temporal sector appear to be larger than those of cells in the nasal sector.

This impression is verified by the soma size histograms shown in Figure 11. While the distributions of soma sizes for the overall ganglion cell population are similar across the vertical meridian, the crossed temporal population contains a significant proportion of cells with soma areas greater than $125 \mu \mathrm{m}^{2}$. Such large cells are absent from the uncrossed nasal population. A preponderance of large cells in the crossed temporal population and their paucity in the uncrossed nasal population is a characteristic of the overlap zone of the adult macaque retina ( $\mathrm{Fu}$ kuda et al., 1989)

Large cells tended to be situated deep in the ganglion cell layer, as is the case for the P $\alpha$ cells in the mature retina (Perry and Silveira, 1988). Moreover, about half of the ganglion cells displaced to the inner nuclear layer were large cells. The nasotemporal overlap of the displaced ganglion cell population was coextensive with that of the large cell population of the ganglion cell layer (Fig. 10B). Although a large cell population was not apparent at earlier ages, a temporal offset of the displaced ganglion cell decussation pattern was evident even at E85 (not illustrated).

Although the overlap zone of the large cells extended furthest into the temporal hemiretina, these neurons did not form an elevated proportion of the ectopic cells in the temporal hemi-

Table 1. Decussation error indicated by the proportions of cells ectopic to the hemiretinas appropriate for the nasotemporal division

\begin{tabular}{|c|c|c|c|c|c|c|}
\hline \multirow[b]{2}{*}{ Age } & \multicolumn{2}{|l|}{ Crossed } & \multicolumn{2}{|c|}{ Uncrossed } & \multicolumn{2}{|c|}{ Combined } \\
\hline & Ectopic & Total (\%) & Ectopic & Total (\%) & Ectopic & Total (\%) \\
\hline E69 & 1400 & $538,000(0.25)$ & 1200 & $303,000(0.40)$ & 2600 & $841,000(0.31)$ \\
\hline $\mathrm{E} 85$ & 1700 & $948,000(0.18)$ & 4500 & $631,000(0.71)$ & 6100 & $1,578,000(0.39)$ \\
\hline E115 & 2500 & $1,022,000(0.25)$ & 1500 & $709,000(0.22)$ & 4100 & $1,731,000(0.24)$ \\
\hline E129 & 1100 & $750,000(0.15)$ & 1200 & $421,000(0.28)$ & 2300 & $1,171,000(0.20)$ \\
\hline
\end{tabular}



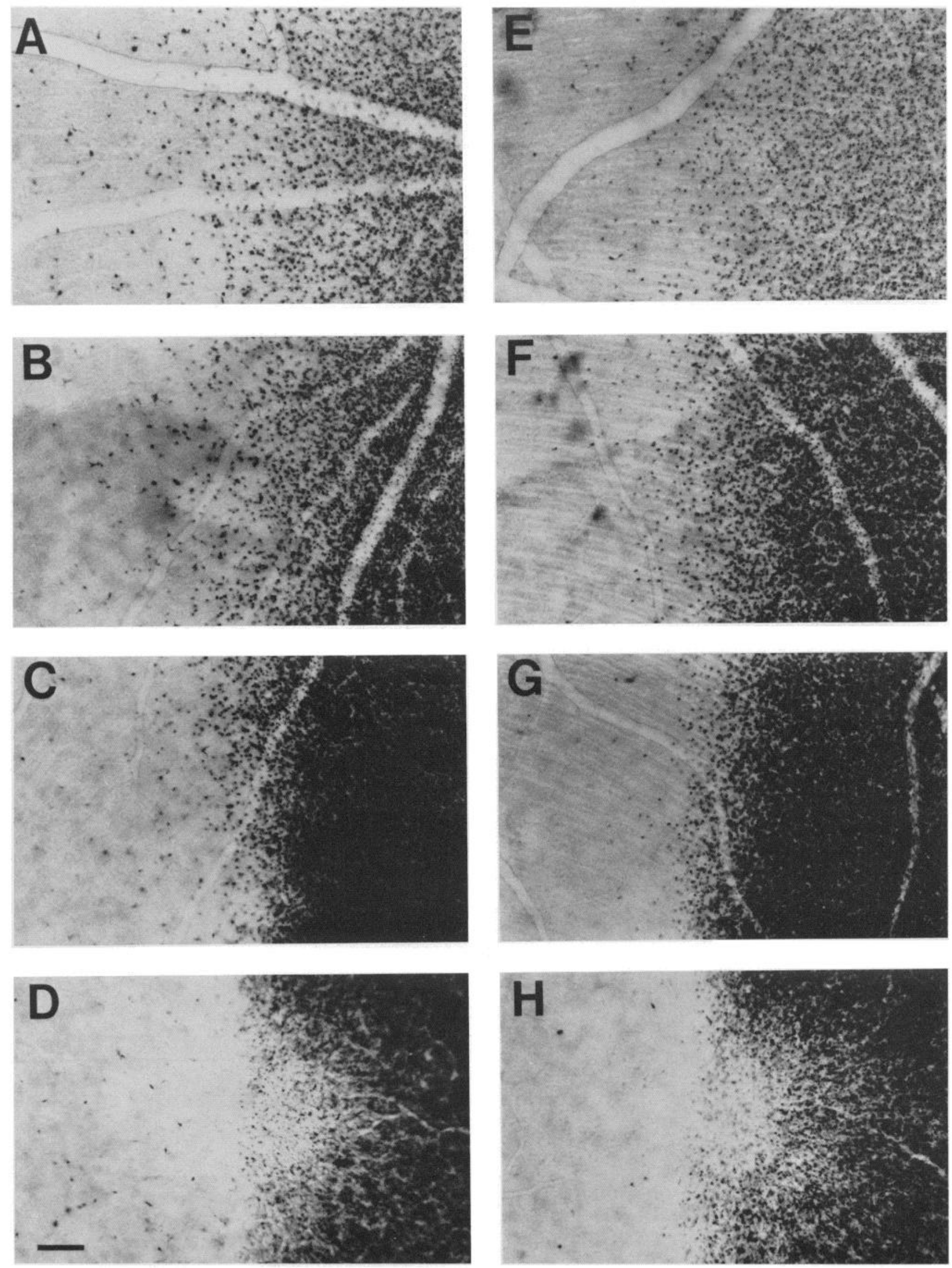

Figure 5. Photomicrographs taken along vertical meridian of each retina of E1 15 fetus illustrating greater dispersion of labeled cells with increasing eccentricity along median edge. $A-D$ are contralateral, and $E-H$ ipsilateral, to the injected optic tract. $D$ and $H$ are at the nascent fovea. $C$ and $G$ are $1.0 \mathrm{~mm}, B$ and $F$ are $2.0 \mathrm{~mm}$, and $A$ and $E$ are $3.0 \mathrm{~mm}$ superior to the fovea centralis. At this age, the full extent of the superior sector of the median edge (from fovea to peripheral margin) is about $10 \mathrm{~mm}$. Scale bar, $100 \mu \mathrm{m}$. 


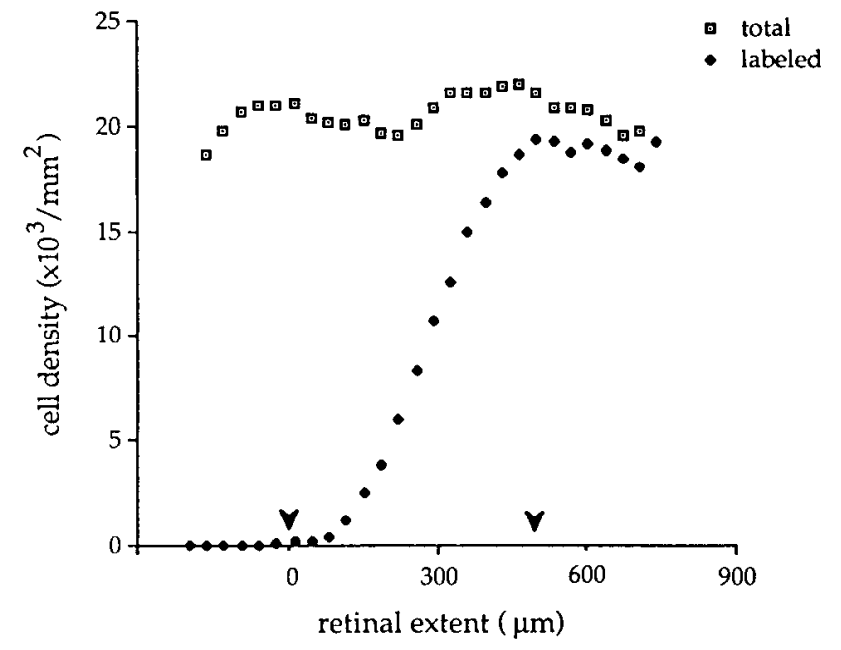

Figure 6. Example of sampling transect of labeled and total cell density in ganglion cell layer perpendicular to median edge across E115 retina. This transect was taken $1.5 \mathrm{~mm}$ superior to the nascent fovea ipsilateral to the injected optic tract. The left arrowhead indicatcs the median cdgc of the uncrossed population. The right arrowhead, at the point of deflection from maximum labeled cell density, indicates the position of the median edge of the crossed population (see text). The distance between these 2 deflection points represents the width of the nasotemporal overlap zone. Temporal is to the right.

retina. This is indicated by the soma size histograms depicted in Figure 12, which compare labeled cell profiles in the peripheral temporal hemiretina contralateral to the injected optic tract (ectopic) to those in an equivalent ipsilateral sector (orthotopic). As may be seen, the soma size distribution of the ectopic and orthotopic populations are not appreciably different. Thus, the temporal offset of the $\mathrm{P} \alpha$ cell overlap zone does not reflect a general tendency for $\mathrm{P} \alpha$ cells throughout the temporal hemiretina to project to the contralateral hemisphere.

\section{Discussion}

We have found a remarkable degree of precision in the partial retinal decussation pattern of the fetal rhesus monkey. As early as E69, nearly $100 \mathrm{~d}$ before birth, very few retinal ganglion cells project to the inappropriate hemisphere. The nasotemporal overlap zone also appears adultlike throughout the gestational period we studied. Furthermore, by E115, when a class of large ganglion cells could first be recognized, the decussation pattern of these cells showed a clear temporal offset, similar to that observed at maturity. These results indicate that very little refinement occurs in the nasotemporal division of the developing primate retina. The formation of this fundamental feature of the primate visual system appears inherent to the developing retina.

Before discussing the findings, we will briefly consider some methodological factors that could have a bearing on the validity of our conclusions. The large unilateral injections we made into the fetal brain appeared to completely involve the optic tract, but in the youngest fetuses, they did not label all the ganglion cells projecting to the injected hemisphere. ${ }^{1}$ This problem is common to developmental studies relying on retrograde tracing,

\footnotetext{
' Comparing our labeled cell estimates to estimates of midorbital ganglion cell axon number (Rakic and Riley, 1983), we have labeled only $30 \%$ of the population at $\mathrm{E} 69,60 \%$ at $\mathrm{E85}$, and about $70 \%$ at E129. At E115, we labeled virtually the entire ganglion cell population.
}
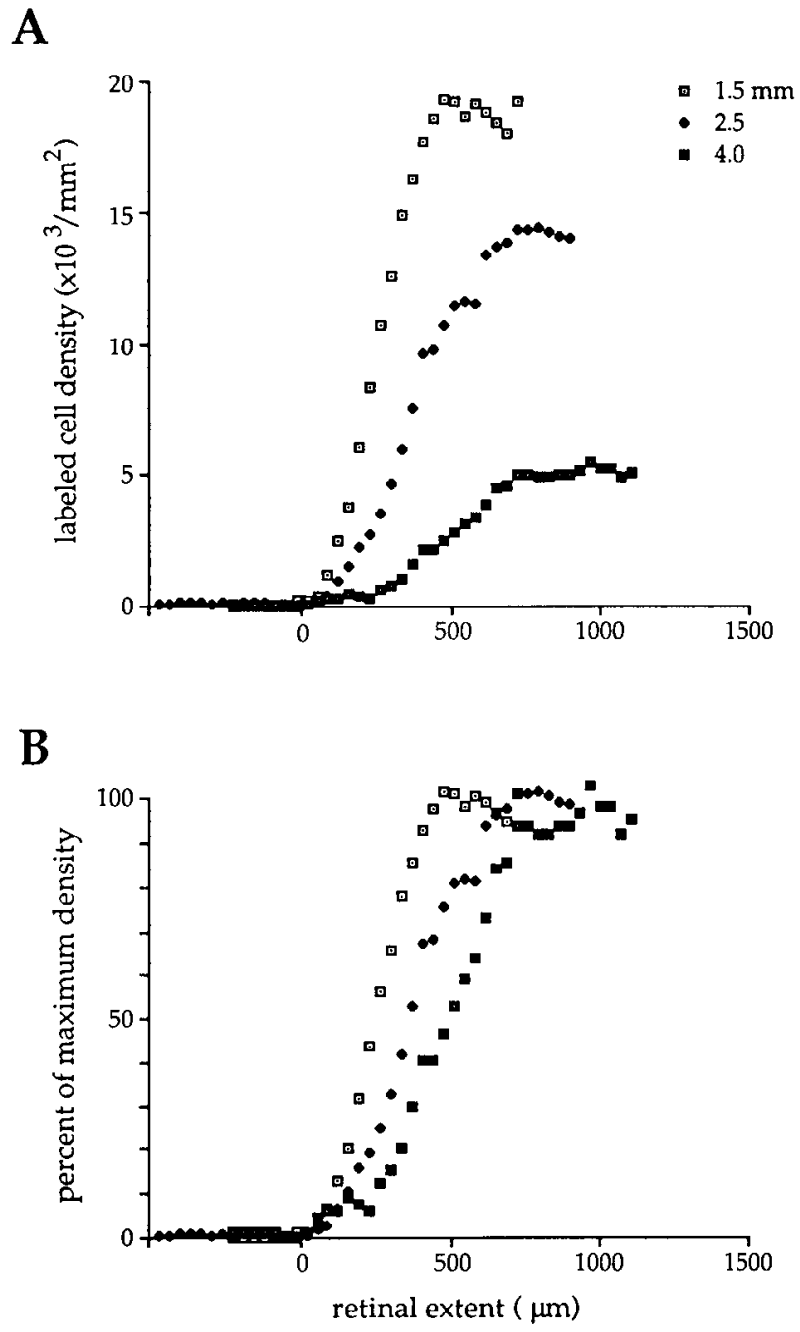

Figure 7. Transition in labeled cell density perpendicular to median edge at 3 eccentricities superior to nascent fovea of E115 retina ipsilateral to injected optic tract. $A$, These curves have been aligned at the median edge $(0$ position). Note that peak density declines with increasing eccentricity, consistent with the overall gradient in ganglion cell topography. $B$, The same data shown in $A$ normalized to maximum labeling density at each eccentricity. This compensates for the normal topographic gradient in ganglion cell density. Note that the distance between the median edge and the point of deflection from maximum labeled cell density, indicating the width of the nasotemporal overlap zone, increases with greater eccentricity. Temporal is to the right.

and it could be argued that our injections failed to label a number of ganglion cells that make chiasmatic errors. In decussation studies dealing with the prenatal cat visual system, we have found that, while the absolute number of ectopic cells can vary among animals of the same age from the same litter, variability is negligible when the error factor is expressed as a proportion of the total number of labeled cells (Lia et al., 1987a; B. Lia and L. M. Chalupa, unpublished observations). Thus, while the absolute number of ganglion cells making chiasmatic errors may well be somewhat greater than that reported here, we believe that our estimates of the proportion of such neurons relative to the overall population of labeled ganglion cells are reasonably accurate and appropriate.

Another potential limitation of the present results is that the proportion of chiasmatic errors early in development may be higher than at E69, the youngest age examined in the present 

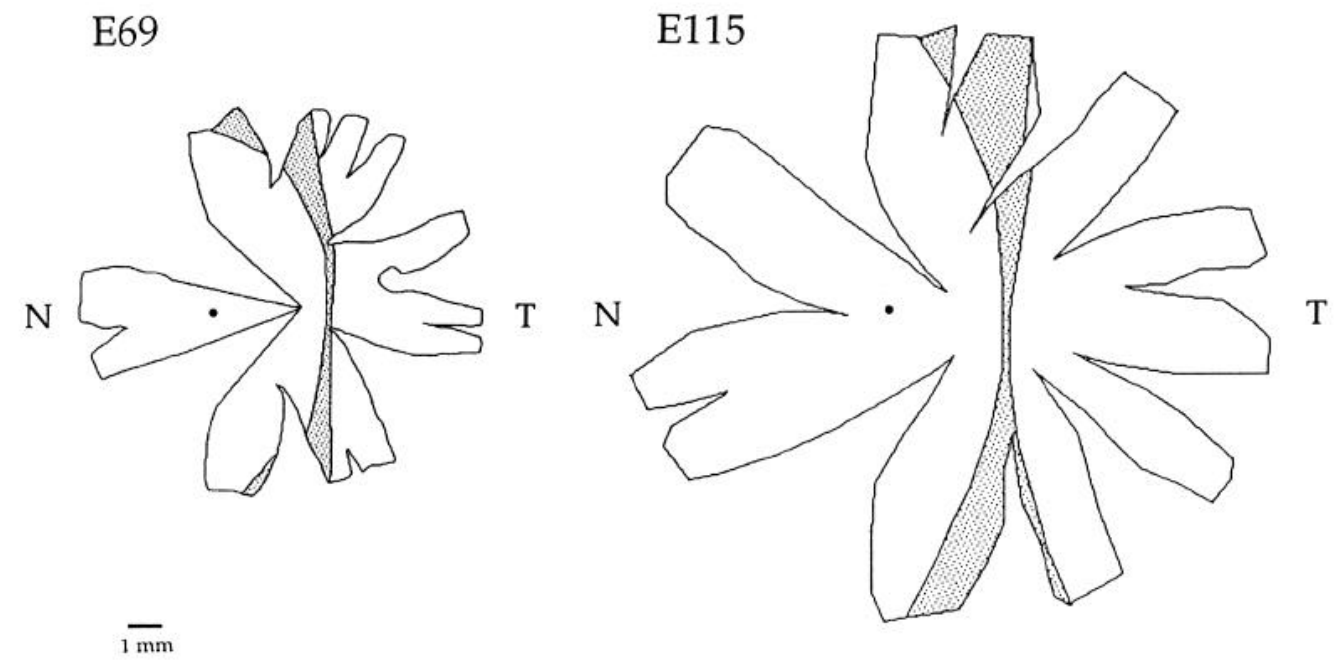

Figure 8. Nasotemporal overlap zone along vertical meridian at E69 and E115, plotted from 11 and 16 sampling transects, respectively, such as shown in Figure 7. Note that the hourglass shape of the overlap zone (stippled) is essentially equivalent at these 2 fetal ages. Each retina is presented at the same scale. $N$, nasal; $T$, temporal.

study. From the data of Rakic and Riley (1983), it appears that the peak number of ganglion cells in the prenatal rhesus monkey is attained around E80. While some retinal ganglion cell axons may be eliminated during the time that the total number of axons in the optic nerve is increasing (e.g., Williams et al., 1986), addition and attrition of optic fibers overlap only for a brief period before the peak number of axons is attained. Thus, it is unlikely that ectopic cells have been eliminated prior to the period we have studied. Nevertheless, it would be of interest to determine the proportion of cells making chiasmatic errors at a time when optic fibers first navigate the primordial optic chiasm. In the rhesus monkey, this occurs around E40 (Gribnau and Geijsberts, 1985).

It should also be noted that the present study assessed the development of the overall decussation pattern, and consequently, we cannot rule out the occurrence of relatively subtle class-specific developmental refinements, as has been documented in the postnatal cat (Leventhal et al., 1988b). As men-

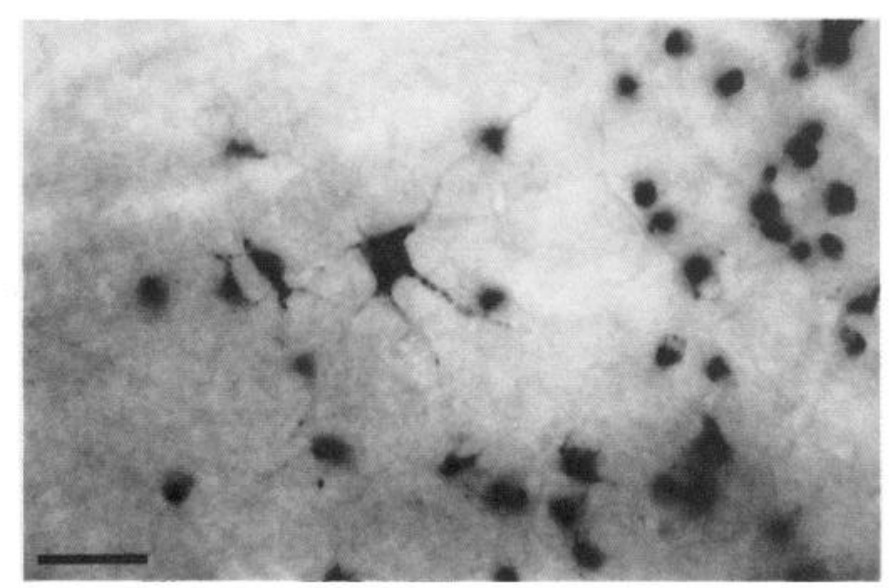

Figure 9. Photomicrograph of $\mathrm{P} \alpha$ cell at E115. The field shown is situated in the temporal half of the nasotemporal overlap zone contralateral to the injected optic tract, about $2 \mathrm{~mm}$, superior to the fovea centralis. Scale bar, $25 \mu \mathrm{m}$. tioned previously, a clear temporal offset of the large cells (presumed to be the P $\alpha$ class) was observed at E115, which suggests that, by this age, class-specific patterns are similar to those found at maturity. Whether this is also the case earlier in development cannot be determined at the present time.

\section{Comparison of developing decussation patterns among mammals}

Retrograde tracing has been used to study the development of decussation patterns in several nonprimate mammalian species, including the rat (Jeffery and Perry, 1982; Bunt et al., 1983; Martin et al., 1983; Fawcett et al., 1984; Jeffery, 1984), mouse (Godement et al., 1987; Collelo and Guillery, 1990), hamster (Insausti et al., 1984; Thompson and Holt, 1989), rabbit (Robinson et al., 1990), ferret (Morgan and Thompson, 1985), and cat (Lia et al., 1987a). In all species, the vast majority of developing retinal ganglion cells have been found to project to the appropriate hemisphere, so that a retinal decussation pattern characteristic of the mature animal is recognizable very early in ontogeny. However, these studies have also noted that a certain proportion of developing ganglion cells make chiasmatic errors.

Previous developmental studies have commonly focused on decussation errors made by the ipsilaterally projecting population of ganglion cells. In all mammalian species, these neurons are confined at maturity (almost exclusively) to the temporal retina. In the newborn rat, Jeffery (1984) has estimated that about $40 \%$ of the ganglion cells projecting to the ipsilateral hemisphere are located outside the temporal crescent, a region to which these neurons are restricted in the adult animal. Similarly, Insausti et al. (1984) have noted that, in the developing hamster, about $1 / 2$ of the ipsilaterally projecting neurons are in the inappropriate region of the retina. In developing carnivores, the proportion of cells making chiasmatic errors is substantially lower, with about $12 \%$ of the ipsilaterally projecting neurons being ectopic in the newborn ferret (Morgan and Thompson, 1985) and in the fetal cat (Lia et al., 1987a). By contrast, the present study has revealed that, in the prenatal rhesus monkey, less than $1 \%$ of ipsilaterally projecting neurons are located in the inappropriate (nasal) hemiretina. Thus, there appears to be 
A

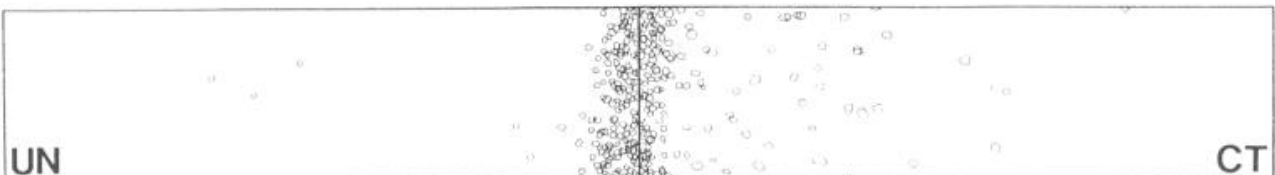

B



Figure 10. Cell profiles within nasotemporal corridor centered on nascent fovea at E115 retina ( $2 \mathrm{~mm}$ across, $275 \mu \mathrm{m}$ wide). The dividing line represents the vertical meridian. $A$, Composite reconstruction of the extent of the nasotemporal overlap zone in the area centralis, prior to the centrifugal redistribution of ganglion cells that occurs later in fetal development. On the right, all labeled profiles of the crossed projection population temporal to the vertical meridian are drawn $(C T)$, and on the left, all profiles of the uncrossed population nasal to the vertical meridian $(U N)$. Note the dispersion of large cells into the crossed temporal sector. $B$, Distribution of those profiles shown in $A$ that are displaced ganglion cells. Note that the displaced population in the crossed temporal sector is roughly coextensive with, and constitutes a relatively large porportion (about 1 in 5) of, the temporalmost cells of the crossed temporal sector shown in $A$.

a trend for error magnitude to be inversely related to the degree of binocularity as judged by the size of the ipsilateral projection.

We are particularly struck by the difference in decussation errors between the fetal cat and monkey because identical pro-

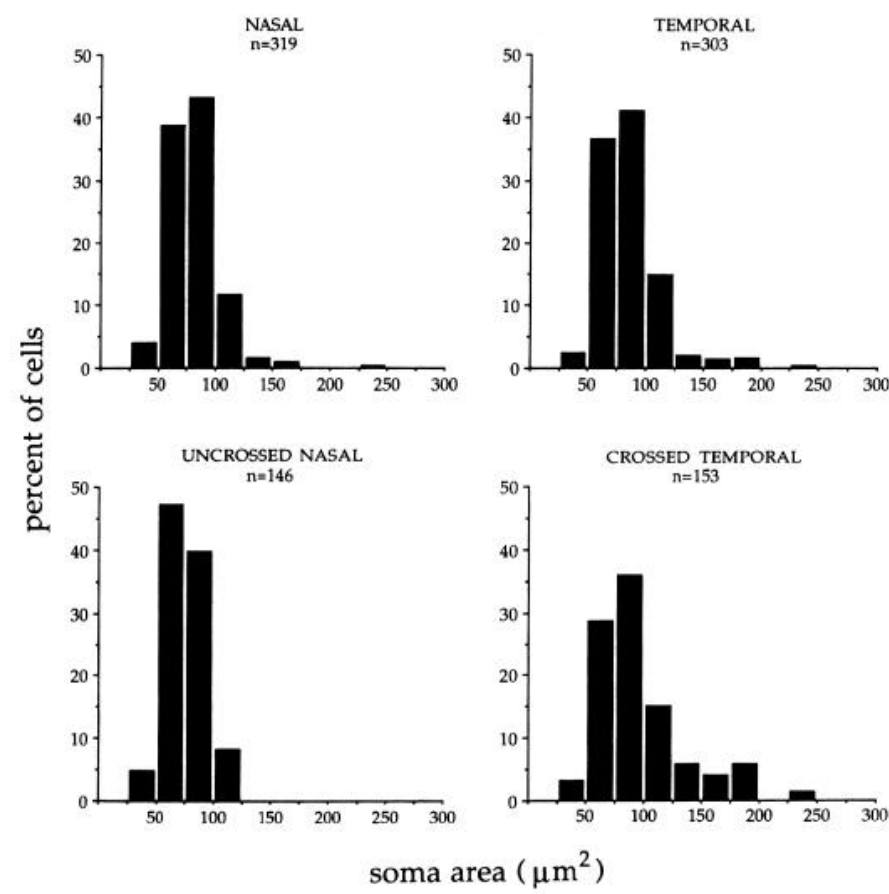

Figure 11. Soma size histograms for labeled cells of nasotemporal overlap zone centered on area centralis of E115 retina. The top histograms show that, for the overall ganglion cell population, the soma size distributions of cells nasal (left) and temporal (right) to the vertical meridian are not appreciably different $(p=0.29$; Kolmogorov-Smirnov test). The crossed temporal population (bottom right) contains a greater proportion of large cells (soma area larger than $125 \mu \mathrm{m}^{2}$ ) than does the overall temporal population (top right), and large cells are lacking in the uncrossed nasal population (bottom left). The uncrossed nasal and crossed temporal distributions are significantly different $(p=$ 0.02 ; Kolmogorov-Smirnov test). cedures were employed to study these 2 species in our laboratory. In the fetal cat, we have estimated the ectopic population for both the uncrossed and the crossed projections (Lia et al., 1987a; Lia and Chalupa, unpublished observations). In terms of overall decussation error, about half as many ectopic cells are present in the developing rhesus monkey as in the fetal cat. This is despite the fact that the fetal rhesus monkey has nearly 5 times the total number of retinal ganglion cells at equivalent stages of development (Rakic and Riley, 1983; Williams et al., 1986).

While an adultlike retinal decussation pattern appears to be basically inherent to all species, our results indicate that the fetal rhesus monkey, a species with the most highly developed binocular vision, is characterized by an unrivaled degree of precision in the specification of the nasotemporal division of retinal ganglion cells with crossed and uncrossed projections.

\section{Developmental implications}

In the fetal macaque, the projections of the two eyes are completely intermingled in the lateral geniculate nucleus and the

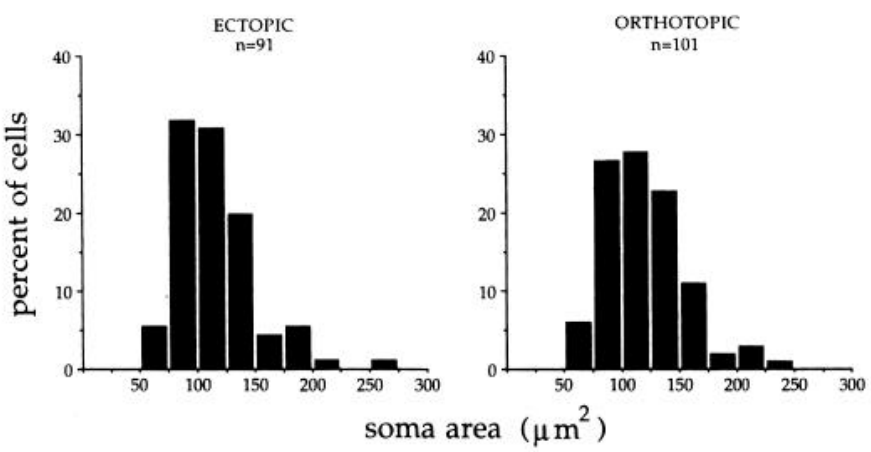

Figure 12. Soma size histograms comparing ectopic labeled cells in peripheral crossed temporal hemiretina (left) with labeled orthotopic cells (right) in equivalent sector of uncrossed temporal hemiretina at E115. There is no appreciable difference between these distributions ( $p$ $=0.44 ;$ Kolmogorov-Smirnov test). 
superior colliculus as late as E78 (Rakic, 1976, 1977). We have found that the nasotemporal retinal decussation pattern in the rhesus monkey is already adultlike at E69. This indicates that early widespread projections in this primate originate almost entirely from the appropriate hemiretina of each eye. In contrast, developmental studies of the rodent visual system have demonstrated previously that both the restriction of retinal projections to specific domains in retinorecipient nuclei (Jeffery and Perry, 1982; Martin et al., 1983; Fawcett et al., 1984; Insausti et al., 1984; Jeffery, 1984; Godement et al., 1987; Thompson and Holt, 1989) and the establishment of retinotopic mapping (Insausti et al., 1985; O'Leary et al., 1985; Simon and O'Leary, 1990) are associated with the death of ganglion cells situated in inappropriate regions of the retina.

As was first shown in the chick (Rager and Rager, 1976), in the rhesus monkey (Rakic and Riley, 1983), and in all other mammalian species studied to date, there is a massive overproduction and elimination of retinal ganglion cells (reviewed by Chalupa, 1988; Dreher and Robinson, 1988; Finlay and Pallas, 1989). Our results indicate that ganglion cell death plays only a very minor role in establishing the primate decussation pattern because an adultlike retinal decussation pattern is present in the rhesus monkey at E69, about $11 \mathrm{~d}$ before there is any evidence for the loss of optic fibers (Rakic and Riley, 1983).

The developmental mechanisms responsible for the guidance of ingrowing axons through the optic chiasm are unknown. It is commonly assumed that this involves the specification of nasotemporal positional information in newborn ganglion cells and the subsequent recognition by the axons of these neurons of some sort of laterality signal expressed at the optic chiasm. Other factors, such as fiber interactions, mechanical guidance, and the time of axon ingrowth, may also contribute to this process (Walsh et al., 1983; Silver, 1984; Godement et al., 1987). These guidance mechanisms are probably the same in all mammals, so most likely, the precision evident in the developing nasotemporal decussation pattern of the rhesus macaque reflects the specialized organization of this primate's retina and its projections.

The macaque retina is dominated by a single class of ganglion cells, with about $80 \% \mathrm{P} \beta$ neurons that project exclusively to the dorsal lateral geniculate nucleus (Leventhal et al., 1981; Perry et al., 1984). In all species, a class of ganglion cells specialized for the retinogeniculate pathway may be more highly specified in terms of laterality than the cell classes that innervate other retinorecipient targets. If this were the case, one would expect that there would be significant differences in the magnitude of chiasmatic errors exhibited by different classes of ganglion cells. Results of studies on the retinal decussation pattern of postnatal cats indicate that $\beta$ cells make fewer and less extensive chiasmatic errors than other ganglion cell classes (Murakami et al., 1982; Jacobs et al., 1984; Leventhal et al., 1988b). The $\beta$ cells of the cat (Walsh et al., 1983; Walsh and Polley, 1985) are the first ganglion cells to be generated, and at maturity, this cell class is distinguished by a very sharp nasotemporal decussation pattern. This implies that laterality information may be more highly specified very early in retinal development, at a time when the class of cells providing the main input to the dorsal lateral geniculate nucleus is being generated. There is evidence that this may also be the case in the developing mouse visual system (Dräger, 1985). Thus, in nonprimate species, developmental decussation errors could disproportionally reflect ectopic cells of the later-generated classes that project to extrageniculate targets. Given the predominance of the retinogeniculate pathway in the rhesus monkey, this could account for the developmental specificity observed in the overall decussation pattern. In this regard, it would be of interest to examine the developing retinocollicular decussation pattern of this primate, which is comprised solely of non-P $\beta$ cells at maturity (Perry and Cowey, 1984).

The primate retina is also distinguished from that of other mammals in that, outside the relatively narrow nasotemporal overlap zone, ganglion cells in the temporal hemiretina project exclusively to the ipsilateral hemisphere. The present study demonstrates that this specialized feature of the primate retina is present very early in development. This suggests that positional markers could completely specify the laterality of primate retinal ganglion cell projections. In nonprimates, neighboring cells in the temporal hemiretina are required to innervate different hemispheres. Even if retinal cells with crossed and uncrossed projections are initially regionally segregated, as suggested by Dräger's (1985) observations on the mouse, at some later stage, the interspersion of neurons with crossed and uncrossed projections presents a formidable challenge to the establishment of decussation patterns based upon retinal positional markers. Consequently, one might expect more decussation errors when neighboring ganglion cells are required to form connections with target nuclei in different hemispheres.

\section{Relation to development of striate cortex callosal connections}

Recently, a remarkable degree of developmental specificity has been found in the callosal connections of the rhesus monkey striate cortex (Dehay et al., 1988; Chalupa et al., 1989). In comparison to other cortical areas of the rhesus monkey (Killackey and Chalupa, 1986; Dehay et al., 1988; Chalupa and Killackey, 1989), and the striate cortex of nonprimates (e.g., Innocenti et al., 1977; Chow et al., 1981; Olavarria and Van Sluyters, 1984), the distribution of callosal projection neurons in the striate cortex of the fetal rhesus monkey appears to be adultlike throughout fetal development. Thus, 2 aspects of neural organization closely related to binocular vision, the nasotemporal decussation pattern and the callosal connections of area 17, appear to be established in the rhesus monkey with minimal reliance on the regressive events that refine the early exuberant connections of other components of the developing visual system.

Because geniculocortical projections appear to be highly ordered topographically in the fetal rhesus monkey even before their invasion of the cortex (Lia et al., 1989), the precise nasotemporal decussation pattern observed in the developing retina could confer upon the striate cortex the specificity displayed by callosal projection neurons. This is in line with the finding that genetically induced aberrations in the nasotemporal decussation pattern are accompanied by corresponding alterations in callosal connections of the visual cortex (Shatz, 1977). There is also evidence that peripheral manipulations can alter the pattern of callosal connections (Innocenti and Frost, 1979; Rhoades and Dellacroce, 1980; Cusick and Lund, 1982; Olavarria and Van Sluyters, 1984). The recent demonstration that removal of the eyes in the fetal rhesus monkey does not alter the callosal connectivity pattern of the striate cortex (Dehay et al., 1989) does not necessarily vitiate this idea. The enucleations were performed after the innervation of the subplate by geniculocortical fibers (Rakic, 1977, 1979). Conceivably, the developmental specificity exhibited by the nasotemporal division of the primate 
retina could prove to be a key factor limiting the exuberance of callosal connections in the striate cortex.

\section{References}

Adams JC (1981) Heavy metal intensification of DAB-based HRP reaction product. J Histochem Cytochem 29:775.

Bunt AH, Minkler DS, Johanson GW (1977) Demonstration of bilateral projection of the central retina of the monkey with horseradish peroxidase neuronography. J Comp Neurol 171:619-630.

Bunt SM, Lund RD, Land PW (1983) Prenatal development of the optic projection in albino and hooded rats. Dev Brain Res 6:149168.

Chalupa LM (1988) Factors underlying loss of retinal ganglion cells. In Cell interactions in visual development (Hilfer SR, Sheffield JB, eds), pp 69-86. New York: Springer.

Chalupa LM, Killackey HP (1989) Process elimination underlies ontogenetic change in the distribution of callosal projection neurons in the postcentral gyrus of the fetal rhesus monkey. Proc Natl Acad Sci USA 86:1076-1079.

Chalupa LM, Killackey HP, Snider CJ, Lia B (1989) Callosal projection neurons in area 17 of the fetal rhesus monkey. Dev Brain Res 46:303-308.

Chow KL, Baumbach HD, Lawson R (1981) Callosal projections of the striate cortex in the neonatal rabbit. Exp Brain Res 42:122-126.

Collelo RJ, Guillery RW (1990) The early development of retinal ganglion cells with uncrossed axons in the mouse: retinal position and axonal course. Development 108:515-523.

Cooper ML, Pettigrew JD (1979) The decussation of the retinothalamic pathway in the cat, with a note on the major meridians of the cat's eye. J Comp Neurol 187:285-312.

Curcio CA, Packer O, Kalina RE (1987) A whole mount method for sequential analysis of photoreceptor and ganglion cell topography in a single retina. Vision Res 27:9-15.

Cusick GC, Lund RD (1982) Modification of visual callosal projections in rats. J Comp Neurol 212:385-398.

Dehay C, Kennedy H, Bullier J, Berland M (1988) Absence of interhemispheric connections of area 17 during development in the monkey. Nature 331:348-350.

Dehay C, Horsburgh G, Berland M, Killackey H, Kennedy H (1989) Maturation and connectivity of the visual cortex in monkey is altered by prenatal removal of retinal input. Nature 337:265-267.

Dräger UC (1985) Birth dates of retinal ganglion cells giving rise to the crossed and uncrossed optic projections in the mouse. Proc R Soc Lond Biol 224:57-77.

Dräger UC, Olsen JF (1980) Origins of crossed and uncrossed retinal projections in pigmented and albino mice. J Comp Neurol 191:383412.

Dreher B, Robinson SR (1988) Development of the retinofugal pathway in birds and mammals: evidence for a common 'timetable.' Brain Behav Evol 31:369-390.

Fawcett JW, O'Leary DDM, Cowan WM (1984) Activity and the control of ganglion cell death in the rat retina. Proc Natl Acad Sci USA 81:5589-5593.

Finlay BL, Pallas SL (1989) Control of cell number in the developing mammalian visual system. Prog Neurobiol 32:207-234.

Fukuda Y, Sawai H, Watanabe M, Wakakuwa K, Morigiwa K (1989) Nasotemporal overlap of crossed and uncrossed retinal ganglion cell projections in the Japanese monkey (Macaca fuscata). J Neurosci 9: 2353-2373.

Godement P, Salaün J, Métin C (1987) Fate of uncrossed retinal projections following early or late prenatal monocular enucleation in the mouse. J Comp Neurol 255:97-109.

Gribnau AAM, Geijsberts LGM (1985) Morphogenesis of the brain in staged rhesus monkey embryos. Adv Anat Embryol Cell Biol 91: $1-69$.

Gundersen HJG (1977) Notes on the estimation of the numerical density of arbitrary profiles: the edge effect. J Microsc 111:219-223.

Hanker JS, Yates PE, Metz CB, Rustioni A (1977) A new specific, sensitive and non-carcinogenic reagent for the demonstration of horseradish peroxidase. Histochem J 9:789-792.

Illing RB, Wässle H (1981) The retinal projection to the thalamus in the cat: a quantitative investigation and a comparison with the retinotectal pathway. J Comp Neurol 202:265-285.

Innocenti GM, Frost DO (1979) Effects of visual experience on the maturation of the efferent system to the corpus callosum. Nature 280: 231-233.

Innocenti GM, Fiore L, Caminiti R (1977) Exuberant projection into the corpus callosum from the visual cortex of newborn cats. Neurosci Lett 4:237-242.

Insausti R, Blakemore C, Cowan WM (1984) Ganglion cell death during development of ipsilateral retino-collicular projection in golden hamster. Nature 308:362-365.

Insausti R, Blakemore C, Cowan WM (1985) Postnatal development of the ipsilateral retinocollicular projection and the effects of unilateral enucleation in the golden hamster. J Comp Neurol 234:393-409.

Jacobs DS, Perry VH, Hawken MJ (1984) The postnatal reduction of the uncrossed projection from the nasal retina in the cat. $J$ Neurosci 4:2425-2433.

Jeffery G (1984) Retinal ganglion cell death and terminal field retraction in the developing rodent visual system. Dev Brain Res 13:8196.

Jeffery G, Perry H (1982) Evidence for ganglion cell death during development of the ipsilateral retinal projection in the rat. Dev Brain Res 2:176-180.

Killackey HP, Chalupa LM (1986) Ontogenetic change in the distribution of callosal projection neurons in the postcentral gyrus of the fetal rhesus monkey. J Comp Neurol 244:331-348.

Leventhal AG, Rodieck RW, Dreher B (1981) Retinal ganglion cell classes in the old world monkey: morphology and central projections. Science 213:1139-1142.

Leventhal AG, Ault SJ, Vitek DJ (1988a) The nasotemporal division in primate retina: the neural basis of macular sparing and splitting. Science 240:66-67.

Leventhal AG, Schall JD, Ault SJ, Provis JM, Vitek DJ (1988b) Classspecific cell death shapes the distribution and pattern of central projection of cat retinal ganglion cells. J Neurosci 8:2011-2027.

Lia B, Chalupa LM (1988) Prenatal development of regional specialization in the primate retina. Invest Ophthamol Vis Sci [Suppl]29: 378.

Lia B, Kirby MA, Chalupa LM (1987a) Decussation of retinal ganglion cell projections during prenatal development of the cat. Soc Neurosci Abstr 13:1690.

Lia B, Williams RW, Chalupa IM (1987b) Formation of retinal ganglion cell topography during prenatal development. Science 236:848851.

Lia B, Snider CJ, Chalupa LM (1988) The nasotemporal division of the retinal ganglion cell decussation pattern in the fetal rhesus monkey. Soc Neurosci Abstr 14:458.

Lia B, Snider CJ, Chalupa LM (1989) Topography and specificity of visual thalamocortical projections in the fetal rhesus monkey. Soc Neurosci Abstr 15:1210.

Martin PR, Sefton AJ, Dreher B (1983) The retinal location and fate of ganglion cells which project to the ipsilateral superior colliculus in neonatal albino and hooded rats. Neurosci Lett 41:219-226.

Morgan JE, Thompson ID (1985) The distribution of ipsilaterally projecting retinal ganglion cells in neonatal pigmented and albino ferrets. J Physiol (Lond) 369:35P.

Murakami D, Sesma M, Rowe M (1982) Characteristics of nasal and temporal retina in Siamese and normally pigmented cats. Brain Behav Evol 21:67-113.

Olavarria J, Van Sluyters RC (1984) Callosal connections of the posterior neocortex in normal-eyed, congenitally anophthalmic, and neonatally enucleated mice. J Comp Neurol 230:249-268.

O'Leary DDM, Fawcett JW, Cowan WM (1986) Topographic targeting errors in the retinocollicular projection and their elimination by selective ganglion cell death. J Neurosci 6:3692-3705.

Packer O, Hendrickson AE, Curcio CA (1989) Photoreceptor topography of the retina in the adult pigtail macaque (Macaca nemestrina). J Comp Neurol 288:165-183.

Perry VH, Cowey A (1984) Retinal ganglion cells that project to the superior colliculus and pretectum in the macaque monkey. Neuroscience 12:1125-1137.

Perry VH, Linden R (1982) Evidence for dendritic competition in the developing retina. Naturc 297:683-685.

Perry VH, Silveira LCL (1988) Functional lamination in the ganglion cell layer of the macaque's retina. Neuroscience 25:217-233.

Perry VH, Oehler R, Cowey A (1984) Retinal ganglion cells that project to the dorsal lateral geniculate nucelus in the macaque monkey. Neuroscience 12:1101-1123. 
Pettigrew JD, Ramachandran HB, Bravo H (1984) Some neural connections subserving binocular vision in ungulates. Brain Behav Evol 24:65-93.

Provis JM, Watson CRR (1981) The distribution of ipsilaterally and contralaterally projecting ganglion cells in the retina of the pigmented rabbit. Exp Brain Res 44:82-92.

Rager G, Rager U (1976) Generation and degeneration of retinal ganglion cells in the chicken. Exp Brain Res 25:551-553.

Rakic P (1976) Prenatal genesis of connections subserving ocular dominance in the rhesus monkey. Nature 261:467-471.

Rakic P (1977) Prenatal development of the visual system in rhesus monkey. Philos Trans R Soc Lond [Biol] 278:245-260.

Rakic $P$ (1979) Genesis of visual connections in the rhesus monkey. In: Developmental neurobiology of vision (Freeman RD, ed), pp 249 260. New York: Plenum.

Rakic P, Riley KP (1983) Overproduction and elimination of retinal axons in the fetal thesus monkey. Science 219:1441-1444.

Reese BE, Cowey A (1987) The crossed projection from the temporal retina to the dorsal lateral geniculate nucleus in the rat. Neuroscience 20:951-959.

Rhoades RW, Dellacroce DD (1980) Neonatal enucleation induces an asymmetric pattern of visual callosal connections in hamsters. Brain Res 202:189-195.

Robinson SR, Sung L, Dreher B, Taylor I (1990) Distribution of ipsilaterally projecting ganglion cells in adult and neonatal rabbits. Proc Aust Physiol Pharmacol Soc 21:128P.

Shatz CJ (1977) Anatomy of interhemispheric connections in the visual system of Boston Siamese and ordinary cats. J Comp Neurol 173:497-518.

Silver J (1984) Studies on the factors that govern directionality of axonal growth in the embryonic optic nerve and at the chiasm of mice. J Comp Neurol 223:238-251.
Simon DK, O'Leary DDM (1990) Limited topographic specificity in the targeting and branching of mammalian retinal axons. Dev Biol 137:125-134.

Stone J (1966) The naso-temporal division of the cat's retina. J Comp Neurol 126:585-600.

Stone J, Leicester J, Sherman M (1973) The naso-temporal division of the monkey's retina. J Comp Neurol 150:333-348.

Streeten BW (1969) Development of the human retinal pigment epithelium and the posterior segment. Arch Ophthalmol 81:383-394.

Thompson I, Holt CE (1989) Effects of intraocular tetrodotoxin on the development of the retinocollicular pathway in the Syrian hamster. J Comp Neurol 282:371-388.

Vitek DJ, Schall JD, Leventhal AG (1985) Morphology, central projections, and dendritic field orientation of retinal ganglion cells in the ferret. J Comp Neurol 241:1-11.

Wakakuwa K, Washida A, Fukuda Y (1985) Ipsilaterally projecting retinal ganglion cells in the eastern chipmunk (Tamias sibiricus asiaticus). Neurosci Lett 55:219-224.

Walsh C, Polley EH (1985) The topography of ganglion cell production in the cat's retina. $J$ Neurosci 5:741-750.

Walsh C, Polley EH, Hickey TL, Guillery RW (1983) Generation of cat retinal ganglion cells in relation to central pathways. Nature 302 : 611-614.

Wässle H, Illing RB (1980) The retinal projection to the superior colliculus in the cat: a quantitative study with HRP. J Comp Neurol 190:333-356.

Williams, RW, Bastiani MJ, Lia B, Chalupa LM (1986) Growth cones, dying axons, and developmental fluctuations in the fiber population of the cat's optic nerve. J Comp Neurol 246:32-69. 